https://doi.org/10.48009/1 iis 2005 353-360

\title{
IMPROVING THE EFFECTIVENESS OF THE ACADEMIC DELIVERY PROCESS UTILIZING SIX SIGMA
}

\author{
Monica C. Holmes, Central Michigan University, monica.c.holmes@cmich.edu \\ Anil Kumar, Central Michigan University, anil.kumar@cmich.edu \\ Lawrence O. Jenicke, Central Michigan University, lawrence.o.jenicke@cmich.edu
}

\begin{abstract}
Universities and colleges have collaborated with businesses in different ways. One fairly common partnership that is stipulated by AACSB is the development of business advisory councils or boards. Corporate members on such boards provide services such as curricular advice, providing internship and job opportunities, and fundraising initiatives. Such boards require a certain amount of nurturing and relationship building. Someone, usually from the university, has to take ownership of keeping the momentum going and the corporate members engaged after the board is set up.
\end{abstract}

Recently, the business college at a regional Midwestern university has been tasked by the executive officers to initiate a pilot project to implement the use of Six Sigma among its faculty. A group of faculty selected by the Dean will be undergoing intensive training by a chemical company.

This paper will examine the reasons for such a partnership to occur, the relevancy of Six Sigma in academia, and the benefits of implementing this philosophy at a university. Finally, the authors discuss how Six Sigma may be implemented in information systems programs.

Keywords: Six Sigma, quality, continuous improvement, corporate collaboration

\section{INTRODUCTION}

The flight of U.S. manufacturing jobs to foreign countries is to some extent replicated in the outsourcing of programming assignments overseas [13]. Unless Information Systems (IS) professionals pay attention to lean systems development practices, more IS jobs will go abroad. Higher education institutions do not typically have a comprehensive approach to quality [12]. While the Six Sigma methodology is usually taught in the operations management or supply chain disciplines in a business college [2, 3,9], other areas do not refer to it at all. Yet, using Six Sigma, it is possible to understand the complexity of an organizational environment. Often the symptoms of organizational problems are fixed instead of the root causes. The root causes of complexity could include standard cost systems, performance measurement and reward. The interrelationships of these root causes add to the complex problems that can be solved by the Six Sigma methodology $[1,4,15]$.

It is also possible for two organizations from different industries to use Six Sigma. In 1997 Citibank used the expertise of Motorola University Consulting and Training Services to improve its customer satisfaction [11]. Using the Pareto chart, Citibank was able to identify those $20 \%$ of possible causes that were the reason for $80 \%$ of the problems. Cross-Functional Process 
Mapping was used to achieve Cycle Time Reduction in the financial areas such as consumer banking. In many ways, Citibank is a service organization and so is an educational institution. Many of the business processes that are used in companies are relevant in academia, which also have to maximize the use of its resources.

\section{THE ENVIRONMENT}

This paper discusses the Six Sigma initiative of a Midwestern regional university with the mentoring by a Fortune 500 company. Both have a long history of working together in several departments across campus. The university has a total enrollment of 27,936 students with 19,792 on campus and another 8,144 off campus. The university offers its growing student population a broad selection of more than 3,000 individual courses and a choice of 25 degrees. With the budget cuts experienced over the last three years by the state legislature, the university has had to operate very efficiently. Several cost-saving strategies have been implemented at this university and this Six Sigma project is viewed as the pilot initiative to become even more efficient. It is also viewed as a way for the faculty to become more business-connected and to provide professional development for them that would enhance their teaching in the classrooms. Students can acquire skills that would enhance their education.

\section{SIX SIGMA}

Six Sigma is a modern, continuous quality improvement philosophy that has provided some well documented improvements to products and profits in many business organizations. It has been successfully applied at organizations such as Motorola (where it originated), General Electric, Texas Instruments, Allied Signal, Eastman Kodak and many other business firms [4, 6, 8, 9]. It emphasizes an ongoing effort to reduce costs, improve customer satisfaction, raise productivity, reduce variation, reduce delivery times and cut defects, all of which strengthen the competitiveness of an organization and improve profitability [5, 6, 7].

The term Six Sigma originally referred to quality measures of process capability that compare the variation in a process that produces a product with the specifications for the product. Six Sigma quality focuses on reducing the process variation (measured by the standard deviation of the process) so that an extremely small number of products are produced that will not meet specifications. Both the process variation and the position of the process mean affect the ability of the process to meet specifications. The process variation is reduced to the point where (for a normally distributed process output), even if the process average is allowed to shift by \pm 1.5 standard deviations from the target specification, there will only be 3.4 defective products per million [6]. Today, the term Six Sigma refers to a broad, organization-wide quality management system that encompasses customers, managers and employees that goes far beyond measuring defects per million.

Six Sigma provides a structured approach to improving quality called the Six Sigma Improvement Model or DMAIC referring to the five steps of the process: Define, Measure, Analyze, Improve and Control (Table 1) [1, 14, 15]. 
Six Sigma also has a role in the design of products or services and the processes that are used to produce them. Design for Six Sigma or DFSS incorporates the probabilistic nature of products and processes into their design. The inherent variation of both products and processes is considered together so that manufacturing defects can be minimized at the product design stage [16]. This requires a formal analysis of the design including manufacturing and assembly, product reliability as well as product performance. The product and process are designed for Six Sigma quality ahead of time rather than an after-the-fact improvement of an existing process.

Another aspect of Six Sigma is the involvement, training and reward of employees at all levels of the organization. Champions at the executive levels guide the selection of projects, securing of

\section{Table 1. DMAIC Overview}

Define A problem definition step that defines the objectives of the quality improvement project as well as who the customers are. More specifically, this could reflect differences between what the customer wants and what the production process can provide that represent areas for improvement

Measure The quality characteristics that reflect product improvements are selected and a measurement system is established to collect data on these characteristics.

Analyze The data collected in the previous step is examined to provide information that will be used to redesign or modify the process to improve it. Quality management tools such as cause-and-effect diagrams, flow charts, scatter diagrams, Pareto charts and statistical process control charts are used to assist in the analysis.

Improve The design changes or process modifications that result in improvements are implemented. Systems are established to collect data from the process reflecting the status of improvements.

Control The process is monitored to ensure that the process improvements are maintained. The ongoing application of quality management tools such as Pareto charts, histograms, scatter diagrams and statistical process control charts are used in the monitoring of the process.

resources and goal setting for improvement efforts. Employees are given martial arts titles reflecting their training and status in project improvement efforts. Master Black Belts train and mentor Black Belts, Black Belts are project team leaders and Green Belts are team members. A portion of management and employee compensation is tied to the success of Six Sigma programs and projects to provide an incentive for participation in improvement efforts $[5,7,17]$.

\section{RELEVANCE TO ACADEMIA}

Academic institutions are involved with three primary functions: teaching, research and service. The administrative function(s), a supporting activity, of a University helps to coordinate and 
support the three primary activities. Both the primary and secondary functions involve multiple activities and operations that help in the smooth functioning of the university. Each of these operations is comprised of processes that define the nature of work flow in a university $[10,12$, 17]. As the objective of implementing Six Sigma is to improve operational performance, it becomes pertinent to identify the relevance of implementing the methodology in a university [18]. Further a university needs to provide evidence of financial gains resulting from implementing Six Sigma.

This paper focuses on the teaching function in a university as the authors are instructors in the Midwestern university. Two of the authors teach in the area of Information Systems and the third author teaches in Operations Management. Teaching in any area involves multiple activities such as program design, curriculum development, aligning learning objectives of individual courses to program learning objectives, classroom instruction, and student learning assessment etc. The Six Sigma methodology can be utilized in all the above listed activities to improve the teaching function.

Information Systems (IS) is a discipline that educates students on using Information Technology (IT) tools to design and develop information systems. These information systems support decision-makers in their decision-making process by helping them convert raw data to meaningful information and subsequently knowledge. The Six Sigma methodology is a datadriven methodology and this aligns well with the IS discipline. IS programs, individual courses and capstone projects can easily apply the principles of Six Sigma methodology. An IS program in a university can use the Six Sigma methodology phases (DMAIC) to design and implement its program and curriculum student learning objectives.

Table 2. DMAIC Principles Applied to an Information Systems Program

D Define the IS program \& curriculum student learning objectives

M Measure student learning in the classroom

A Analyze student learning in the classroom

I Improve student learning based on the data analysis

C Control plans that institutionalize the improvements for the future to ensure that student learning stays at a desired level

The Six Sigma methodology principles can be used in designing IS courses in a manner that highlights the significance of data and data analysis in an organization. Systems analysis and design courses in an IS program emphasize gathering requirements that help meet users' needs in their work environment. Students can use Six Sigma principles to better understand what data is useful (Measure) when gathering requirements and how to avoid collecting data that distracts rather than help a user. Systems analysis and design courses that use tools such as Fishbone Analysis and Cause-Effect matrix can be used to depict the Analyze phase in Six Sigma. 
Advanced database courses can be used to help students understand how to extract data from multiple information systems to enable Analysis of data. Decision support systems and similar courses can also be used to demonstrate Analysis of organizational data.

The capstone IS course normally requires students to work on a project that integrates the knowledge they have acquired from different courses in the program. Students can develop projects using the design and development of systems that support Six Sigma initiatives in an organization. For example, students can be asked to develop systems that help organizations align their system to a data analysis tool such as JMP that is used for Six Sigma Analysis phase. This ensures that there will be no problems extracting organizational data to an analysis tool.

As is evident from the preceding paragraphs there are plenty of opportunities for educators to integrate Six Sigma principles into the teaching function. It would be interesting to see the impact of this integration.

\section{THE PROJECT}

In this case a Midwestern university has collaborated with a Fortune 500 company to explore the potential benefits of implementing Six Sigma in an academic institution. The Fortune 500 company has been successfully using the Six Sigma methodology for almost 10 years. The methodology is institutionalized and there is an ongoing effort to certify the majority of the employees. The company has their own certification process and they conduct certification training on a regular basis. Every year employees from worldwide locations attend the training and complete a project that demonstrates financial benefits to the company.

The university has been looking for opportunities to improve its operational efficiency to reduce the impact of budget cuts in the past few years. As an initial step in this direction 12 faculty from the College of Business Administration have been selected to undergo Black Belt certification training. Each participant in this training will work on a project. All projects are based in the university and involve multiple departments, e.g., IT helpdesk, budgeting, and admissions. The training is expected to be completed in summer 2005. Every month for four months, the trainees will attend a weeklong session where they will be taught the phases (DMAIC) of Six Sigma. Individual faculty members will work on their projects simultaneously with the training. On completion of the four month training it is expected that it would take between 6-9 months for the improvements to be implemented and institutionalized. At that point if all goes well the participants will receive their Black Belt certification. Then perhaps the next group of university faculty and staff will attend the next wave of Black Belt certification training.

\section{CHALLENGES OF APPLYING SIX SIGMA IN AN ACADEMIC SETTING}

The application of Six Sigma methodology to a university environment presents some unique challenges not found in a manufacturing setting. Quality management and improvement techniques including Six Sigma have been more thoroughly developed and refined in manufacturing environments than service systems [8]. Applications of Six Sigma at Motorola, General Electric and Allied Signal have yielded well documented improvements to products and profits. Universities, which are predominantly services, are another story. The nature of the 
product, definition of customers, measurements of quality and employee reward systems differ significantly from those of manufacturing.

A university is in full operation for only nine months of the academic year, i.e., from late August to early May. A company operates for 12 months annually and it also can be more outcomeoriented. On the other hand, in academia, shared governance can mean a much slower decision making process. Students at a university are also partially responsible for their own learning. This one factor complicates the problem significantly. Measures used with Six Sigma in the corporate world sometimes cannot be used in academia. In conclusion, while there is merit in the application of Six Sigma in academia, it would be interesting to see how this project will progress.

\section{ANTICIPATED BENEFITS AND CONCLUSION}

It is expected that there would be significant improvements in operational performance. At the same time, because this is the first wave of Black Belt training and the initiation of the Six Sigma methodology, care has been taken to ensure that none of the projects would result in the elimination of anyone's job. Care is also taken to ensure that the commitment to customer satisfaction comes before efficiency. Usually there is a trade-off between customer satisfaction and efficiency. While in the corporate partner setting, a significant financial impact is required before a Six Sigma project is initiated, such a financial limit is not imposed in the academic setting. Instead, recognition is given to the fact that there are many differences between the corporate world and academia. At the same time, it is recognized that universities can use Six Sigma for continuous improvement in many of the ways they do businesses.

\section{REFERENCES}

1. Bank Deposits: A Black Belt Case Study. Retrieved from http://www.isixsigma.com/library/content/c010318a.asp on 2/19/2005.

2. Brewer, P., Feriel, T., Davig, W. \& Spain, J. (2002). Quality in the Classroom. Quality Progress, 35(1), 67-68.

3. Chambers, D. W. \& Fernandez, A. (2004) The Quality of Learning. Quality Progress, 37(3), 51.

4. Douglas, P. C. \& Erwin, J. (2000). Six Sigma's Focus on Total Customer Satisfaction. The Journal for Quality and Participation, 23(2), 45.

5. Erwin, J. \& Douglas, P.C. (2000). It's Not Difficult to Change Company Culture. SuperVision, 61(11), 6.

6. Evans, J.R. \& Linsday, W.M. (1996). The Management and Control of Quality ( $3^{\text {rd }}$ ed.). West Publishing. 607-609.

7. Goodman, J. \& Theuerkauf, J. (2005). What's Wrong with Six Sigma? Quality Progress, $38(1), 38$.

8. Gowen, C. R. \& Tallon, W. J. (1999) Quality Management Practices in Manufacturing and Service Corporations: How are They Different? Mid-American Journal of Business, 14(1), 33-40.

9. Gross, J. M. (2001). A Road Map to Six Sigma. Quality Process, 34(11), 28-29. 
10. Hoerl, R. \& Bryce, G. R. (2004) What influence is the Six Sigma movement having in universities? What influence should it be having? ASQ Six Sigma Forum Magazine, 3(2), 3739.

11. Rucker, R.. (2000). Citibank's cycle ride to satisfaction. Human Resource Management International Digest, 8(4), 26-27.

12. Seymour, D. (1993). On Q: Causing quality in higher education. Phoeniz, AZ: Oryx Press.

13. Shukla, A. (2005). The Flight of U.S. Manufacturing: Challenge and Response. Cost Management, 19(1), 18, 6 pgs.

14. Six Sigma - What is Six Sigma? Retrieved from http://www.iSizSigma.com on 2/19/2005.

15. The Dow Quality Management System Manual. Retrieved from http://www.dow.com/about/aboutdow/qualinit/index.htm on 5/2/2005.

16. Treichler, D., Carmichael, R., Kusmanoff, A., Lewis, J. \& Berthiez, G. (2002). Design for Six Sigma: 15 Lessons Learned. Quality Progress, 35(1), 38-40.

17. Watson, G. H. (2003). Your opinion: What does it take to be a Master Black Belt? ASQ Six Sigma Forum Magazine, 2(3), 34, 8 pages.

18. Wendt, R. (1994). Learning to 'Walk the Talk' A Critical Tale of the Micropolitics at a Total Quality University. Management Communication Quarterly, 8(1), 5, 41 pages. 